\title{
SIMULATION OF CHEMICAL ACCIDENTS WITH ACETYLENE IN „MESSER TEHNOGAS“ KRALJEVO PLANT BY „ALOHA“ SOFTWARE PROGRAM
}

\author{
DANIJELA ILIĆ KOMATINA ${ }^{1 *}$, JOVANA GALJAK $^{1}$, SVETLANA BELOŠEVIĆ $^{1}$
}

${ }^{1}$ Faculty of Technical Sciences, University of Priština, Kosovska Mitrovica, Serbia

\begin{abstract}
Chemical plants are generally associated with potentially high risk of chemical accidents. During chemical accidents hazardous substances jeopardize human lives, destroy material assests and degrade natural environment. The release of flammable and explosive gases or liquids especially poses a significant threat to the environment. This paper introduces the simulation of a chemical accident caused by an uncontrolled acetylene cylinder release in the warehouse of Messer Tehnogas Kraljevo chemical plant. The simulation was performed by ALOHA program package which defines a possible accident development and determines threat and safety zones. The assessment of potential scenarios is based on physico-chemical properties of the substance causing the accident. This paper discusses accident situations occurring under the most unfavorable atmospheric conditions.
\end{abstract}

Keywords: Hazardous substances, Acetylene, Chemical accident, Simulations, Releaser, Messer Tehnogas Kraljevo, "ALOHA" software.

\section{INTRODUCTION}

Chemical industry is one of the major potential environmental pollutants. A great variety of its negative impacts affect both living organisms and material assets. This group of pollutants includes not only chemical factories, plants, warehouses of hazardous substances, and petrochemical industry, but all industrial complexes using dangerous substances in their production processes. Due to the high level of risk during its working performance, the activities of chemical industy have been frequently disputed.4 A large number of various hazards are reported especially with organic matters (Bogdanović, 2008).

\section{THEORETICAL PART}

\section{Hazardous substances and chemical accidents}

According to European Union Directive-Seveso II, a chemical accident is defined as a result of unplanned and unpredicted events in the course of industrial activity being manifested through emission of toxic substances in the environment or through fire or explosion. The accidents comprising one or more hazardous chemicals jeopardize humans and environment both immediately or with delay, inside or outside the installation. Chemical industrial processes using flammable and/or toxic substances under different pressures and temperatures are exceptionalaccident-prone sites (Abassi et al., 2013; Khan \& Abassi, 1998a). It happens quite frequently that initial fires and explosions within the plant are initiators of new fires or explosions causing the so called "domino effect" enabling primary accident to be spread outside the building and

\footnotetext{
* Corresponding author: danijela.ilic@pr.ac.rs
} CHEMISTRY grown into widespread disaster (Khan, 1998b; Khan, 2001). These accidents kill a huge number of people and cause million euro losses.

According to International Labour Organization (ILO), chemical accidents occur during processing (40\%), storage $(25 \%)$ or transportation $(35 \%)$ of hazardous substances. The major causes of chemical accidents appear to be human factor in $62 \%$ of cases and outdated technology in $20 \%$ of cases. Statistics show that, compared with all natural catastrophes, the highest number of casualties results from chemical accidents (Varma, 2005). As reported by International Labour Organization, around 6000 people per day or 2.2 million people per year die from workplace accidents or consequences of professional illnesses.

Depending upon the place of origin, chemical accidents can be classified as those occurring in fixed facilities (plants, warehouses, oil pipelines) and those occurring during the transport of chemicals. Figure 1 shows the fire in the acetylene warehouse in Dallas 2007. According to the area affected by them, chemical accidents can be categorized as local, regional, national, and global. The most significant factors affecting the spreading of chemical accidents in space and time include physico-chemical properties of hazardous substance and meteorological, hydrological, and geological conditions of the location. Negative consequences resulting form chemical accidents are:

Release of hazardous pollutants (toxic, flammable, corrosive substances) into air, water or soil.

Explosions of substances including both the formation of a strong impact wave and the emission of toxic substances into atmosphere.

Fires being followed by both the formation of toxic and flammable gas clouds and solid combustion products. 
Numerous chemical accidents have been recorded both locally and worldwide (Bogdanovic, 2009). Some of major world chemical accidents should be mentioned: Flixborough (1974), Seveso (1976), Bhopal (1984), Basel (1986), Mexico (1988), Enschede (2000), AZF Toulose (2001) (Sengupta et al., 2016). Tragic consequences of these events initiated multiple efforts in order to increase chemical process safety. Regarding that, many articles and books have been written (Crowl \& Louvar, 2001; Mannan, 2013; Sanders, 2015) as well as procedures concerning safety improvements while processing, using, and handling hazardous substances.

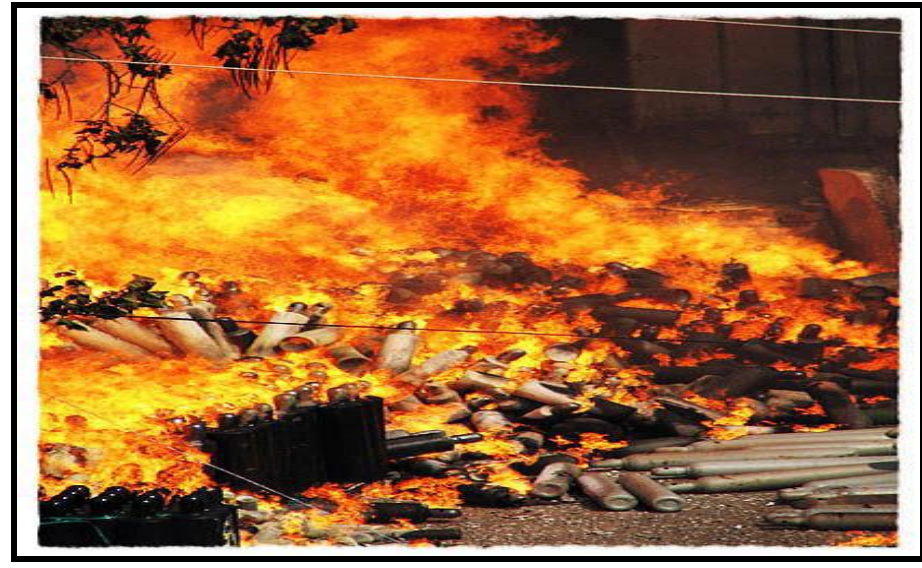

Figure 1. Fire in acetylene warehouse, Dalas, Texas, 2007. Source: http://canaryperch.com/evac9McLain.html

\section{Acetylen - dangerous chemical}

Acetylen $\left(\mathrm{C}_{2} \mathrm{H}_{2}\right)$ is the simplest unsaturated hydrocarbon belonging to alkyne group. Its molecule is linear and built up from two carbon atoms bonded together in a triple bond. One hydrogen atom is bonded to every carbon atom.

At normal temperature and pressure, pure acetylene is colorless, odorless, and tasteless. It is lighter than air and highly flammable. It is one of the most dangerous gases regarding flammability and explosivity. It burns in air with a bright flame whereas in oxygen it burns with a very hot flame reaching 3100 ${ }^{0} \mathrm{C}$. The physico-chemical characteristics of acetylene are shown in Table 1. Due to the presence of phosphine and hydrogen sulfide, technical acetylene has specific garlic-like odor. As a result of a high flame temperature, acetylene is widely used in welding and metal cutting. Acetylen is often used as an alternative fuel or as an additive in reducing NOx emission in internal combustion engines (Lakshmanan \& Nagarajan, 2010a; Lakshmanan \& Nagarajan, 2011b).

Handling with acetylene under the pressure being below atmospheric pressure appears to be quite safe. However, under higher pressures, due to the presence of unstable triple bond in its molecule, acetylene itself becomes highly unstable. Due to the energy impact, this gas undergoes the process of decomposition the result of which flammable hydrogen and elementary carbon are obtained. Exothermic reactions release a great deal of energy with temperatures ranging from $2800{ }^{0} \mathrm{C}$ to $2900{ }^{0} \mathrm{C}$. The acetylene decomposition can result in external and compressive heating, electric sparks, or a strong impact wave. Acetylene is known to be able to decompose even under the condition of complete lack of air. (Carver et al., 1972) Due to the energy impact or under the higher pressure, acetylene can decompose in the cylinder in the completely inert atmosphere. In the course of this process, $226.5 \mathrm{~kJ}$ of heat per mole is released so compressed acetylene can behave as a very strong explosive. Combined with air, acetylene under pressure is easily flammable even at low temperatures. Acetylene has a low ignition energy (minimal ignition energy is $0.019 \mathrm{~mJ}$ ) and it possesses a high speed of chemical energy release making it a very hazardous gas.(Sarkar, 1990). The boundaries of its explosivity in the mixture with air range from $1.5-82$ vol\%, whereas with oxygen those intervals range from $2.3-93 \mathrm{vol} \%$

Table 1. Physico-chemical characteristics of acetylene.

\begin{tabular}{|l|c|}
\hline Chemical formula & $\mathrm{C}_{2} \mathrm{H}_{2}$ \\
\hline Name & Acetylene, Ethyne (IUPAC) \\
\hline The molar mass & Colorless gas \\
\hline Appearance & Odorless \\
\hline Odor & $1,097 \mathrm{~g} / \mathrm{L}$ \\
\hline Density & $-80,8^{\circ} \mathrm{C}$ \\
\hline Melting point & $-84^{0} \mathrm{C}$ \\
\hline Sublimation conditions & $245,85 \mathrm{kPa}\left(\right.$ on $\left.20{ }^{\circ} \mathrm{C}\right)$ \\
\hline Vapor pressure & 25 \\
\hline Acidity (pKa) & $305{ }^{0} \mathrm{C}$ \\
\hline Self-ignition temperat. & $2,3-81 \%$ \\
\hline Limits of explosive mix & \\
\hline
\end{tabular}

At higher temperatures and under higher pressures, acetylene decomposes spontaneously releasing a large quantity of energy and causing chain reactions which result in explosion. Uncontrolled acetylene release during production processes, transportation, or storaging can lead to explosions and detonations endangering safety of people and material assets.

Acetylene can also be associated with chemical explosions followed by detonation combustion characterized by a strong impact wave and deflagration combustion characterized by intense thermal radiation. Damaging effects of detonation and deflagration combustion in free space spread rapidly and can easily overcome the zero zone of regular fire impact. These conditions cause significant material devastations, human casualties, and ecological disasters.

Pure acetylene is not toxic but in high concentrations it has a narcotic and irritating effect on people. Strong impact waves during explosions can lead to blast injuries. 
Handling acetylene conforms with special regulations strictly excluding sudden cylinder discharging, mechanical smashing, heating, and uncontrolled change of volume/pressure proportion. Acetylene that is stored or transported must be properly labeled as shown in Table 2.

High potential for explosive acetylene decomposition can be significantly decreased by mixing it with inert gases or dilluting it in suitable solvents. For this reason acetylene is stored in steel tanks, under pressure of 18 bar, dilluted in acetone. Various types of special porous materials are added into tanks in order to provide additional safety in acetylene handling.

Table 2. Acetylene labeling.

\begin{tabular}{|c|c|c|c|c|}
\hline \multicolumn{5}{|c|}{ Package and storage labeling } \\
\hline Class & \multicolumn{2}{|c|}{$\mathrm{F}+$} & & \\
\hline \multicolumn{5}{|c|}{ NFPA 704 standard labeling } \\
\hline $\begin{array}{l}\text { Health hazards } \\
\text { (1)- low risk }\end{array}$ & \multicolumn{2}{|c|}{$\begin{array}{c}\text { Fire hazards } \\
\text { (4)-easy } \\
\text { flammable } \\
\end{array}$} & $\begin{array}{l}\text { Reactivity } \\
\text { (3)-risk of } \\
\text { explosion }\end{array}$ & $\begin{array}{l}\text { Not } \\
\text { reacting } \\
\text { with water } \\
\end{array}$ \\
\hline \multicolumn{5}{|c|}{ Transport labeling } \\
\hline $\begin{array}{c}\text { Hazardous } \\
\text { substance class }\end{array}$ & 2,1 & \multicolumn{2}{|c|}{$\begin{array}{c}\text { Flammable } \\
\text { gas }\end{array}$} & \\
\hline Kemler code & 239 & \multicolumn{2}{|c|}{$\begin{array}{c}\text { Flammable } \\
\text { gas, easy } \\
\text { reactive }\end{array}$} & $\frac{239}{1001}$ \\
\hline UN number & \multicolumn{3}{|c|}{1001} & \\
\hline CAS number & \multicolumn{4}{|c|}{$74-86-2$} \\
\hline
\end{tabular}

Simulation of chemical accidents

Prior to the chemical accident, the estimate of its impact to the environment is performed whereas the further calculation of its imact is done only after the accident. Ecological risk of an accident can be estimated based on possible scenarios where modelling provides us with the insight into endangered zones in real space and time.

Cities hosting plants which process, remanufacture or storage hazardous substances, carry a higher risk of chemical accidents (Sanchez et al., 2018) Therefore, the simulation of hazardous substance release in industrial plants has become important in prevention and assessment of negative impacts of chemical accidents, in environment protection and workplace safety increase (Shao \& Duan, 2012; Huang et al., 2015). Numerous mathematical models have been developed as useful tools for prediction of accidents in chemical processes (El
Harbawi et al., 2008). Each simulation of chemical accident represents a unique scenario.

This paper focuses on chemical accidents caused by acetylene cylinder release in the warehouse of Messer Tehnogas Kraljevo plant. The description of possible accident sdevelopment, threat zones and impact on the environment was done by software program ALOHA (Areal Locations of Hazardous Atmospheres). This program was developed by team efforts of Environmental Protection Agency (EPA) and National Oceanic and Atmospheric Administration (NOAA) of the USA. ALOHA is a part of CAMEO (Computer Aided Managament of Emergency Operations) software package. Not only does it function as an independent program, it also works with CAMEO Chemicals and MARPLOT programs. ALOHA is widely used to plan for and respond to chemical emergencies. ALOHA program's database contains over 1000 pure chemicals with ability to add new or modify the existing ones. ALOHA is a modelling program that estimates threat zones, including the clouds of toxic gas, fire and explosions. The threat zone is an area where a hazard i.e. a risk (such as toxicity, flammability, thermal radiation or damaging overpressure) has exceeded a user-specified Level of Interest, the Level of Risk or the Level of Concern - LOC (Jovanović, 2013). This program should be avoided in cases of chemical mixtures, indoor simulations, atmospheric fallouts, and in cases of distances farther than $10 \mathrm{~km}$ from the hazardous chemical release source. It is not suitable for simulations in urban areas with many tall buildings and where there is a probability for "canyon effect".

\section{EXPERIMENTAL}

\section{Plant Messer Tehnogas Kraljevo}

Messer Tehnogas company is the biggest producer and distributor of industrial, medical, and special gases in Serbia and in the Balkans. It supplies over 4000 buyers in Serbia and it delivers over $650000 \mathrm{t}$ of products per year. This company trades with gases produced in its own plant such as oxygen, hydrogen, helium, argon, carbon dioxide, acetylene. Beside the product distribution, the plant in Kraljevo also produces acytelene gas. It is located in the southern part of the city, in the urban area called Ribnica in Izletnička Street. As can be seen on the satellite picture of the plant (Figure 2), it is located in the urban part of the colony. The lowland terrain on which the plant was built lies at the altitude of $196 \mathrm{~m}$. The plant is located at latitude $43^{\circ} 42^{\prime} 32^{\prime \prime}$ and longitude $20^{\circ} 41^{\prime} 36^{\prime \prime}$. The total area of plant complex is around 5.0 ha. Since the plant is situated in the urban area, the population likely to be under the direct negative impact of the accident is estimated to be as high as 1000 people.

Primary school "Vuk Karadžić" being attended by 472 pupils is $100 \mathrm{~m}$ northwest from the plant. Local Community Health Center is $100 \mathrm{~m}$ north from the plant. Cultural Center "Ribnica" is also placed nearby the plant. Residential buildings 
are situated around the plant facilities. The river Ribnica flows $50 \mathrm{~m}$ far from the eastern plant facility and at $500 \mathrm{~m}$ on the north it flows into the Ibar. The nursery of "Srbijašume" producing desiduous and coniferous tree seedlings lies in the southwest of the plant.

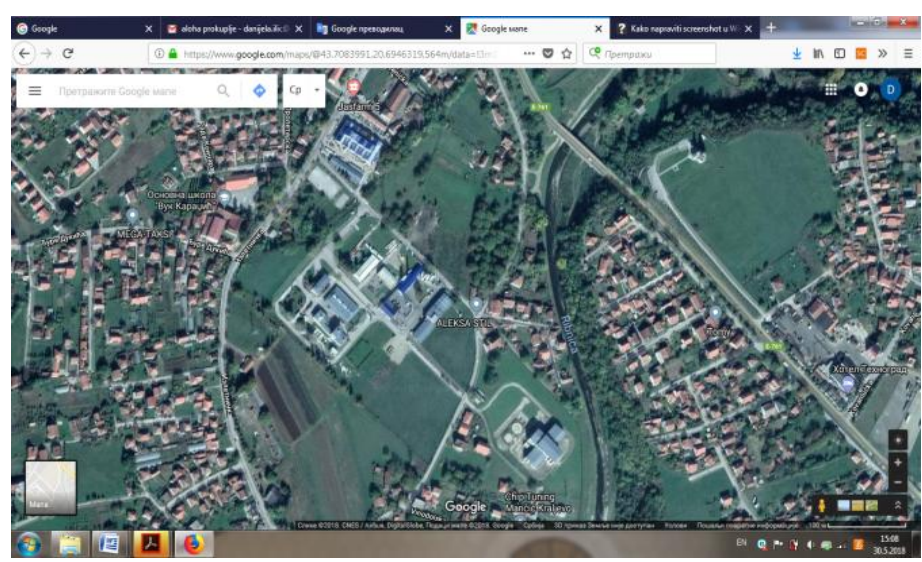

Figure 2. Satellite picture of the plant and surroundings.

The part of the plant where acetylene is stored was selected as the focus of the accident simulation, and fire and explosion risk analysis.

\section{Simulations of acetylene release}

This scenario implies a visualization of possible hazards by determining threat zones, accident extent, and consequences of immediate exposure to chemical impact on the selected area. In order to model an accident, quantitative and qualitative data are required: information on the chemical compound involved (quantity, state of matter, physico-chemical and ecotoxicology properties), accident location data, and current meteorological conditions under which unpredicted events occur.

This paper investigates the scenario leading to the gas diffusion from acetylene cylinder in the warehouse caused by tank wall damage (cracking). Acetylene tank is cylider-shaped and has a $0.5 \mathrm{~m}$ diameter and a length of $2 \mathrm{~m}$. It is filled to $90 \%$ of its volume. The dimensions of the cylinder wall damage made at the height of $0.1 \mathrm{~m}$ from the ground, are $0.100 \times 0.05 \mathrm{~m}$.

The simulation of acetylene release was performed under the most unfavorable meteorological conditions. Starting from experiential data, these conditions include wind speed of $1.5 \mathrm{~m} / \mathrm{s}$, the highest daily temperature, the average humidity matching the location and the temperature, and atmospheric stability of F class (Cvetanović, 2015).

Atmospheric conditions, given in Table 3, representing input data in the software are retrived from the internet site of Republic Hydrometeorological Service of Serbia (RHSS). These data show that western and eastern winds are the most frequent on the territory of the municipality of Kraljevo. Other wind types are not so present at this locality. Based on the geographical position of the warehouse in the plant complex, the eastern wind is deduced to make the most serious damage therefore it was taken as an atmospheric parameter for the simulation.

In the process of fire and explosion modelling, the boundaries of zones with damaging effect exposure should be determined (demolition, overpressure of impact wave, thermal energy effects) and the safety zone for people and objects should be defined.

Table 3. Meteorological data for Kraljevo, RHSS.

\begin{tabular}{|l|c|c|c|c|c|c|}
\hline \multicolumn{1}{|c|}{ Month } & $\begin{array}{c}\mathrm{T}_{\max } \\
\left({ }^{0} \mathrm{C}\right)\end{array}$ & $\begin{array}{c}\mathrm{T}_{\min } \\
\left({ }^{0} \mathrm{C}\right)\end{array}$ & $\begin{array}{c}\text { Wind (E) } \\
\text { speed } \\
(\mathrm{m} / \mathrm{s})\end{array}$ & $\begin{array}{c}\text { Wind (W) } \\
\text { speed } \\
(\mathrm{m} / \mathrm{s})\end{array}$ & $\begin{array}{c}\text { Relative } \\
\text { humidity } \\
(\%)\end{array}$ & $\begin{array}{c}\text { Cloudiness } \\
(\mathrm{x} / 10)\end{array}$ \\
\hline January & 17.1 & 15,6 & 2,2 & 2,1 & 84 & 7,2 \\
\hline February & 24,8 & $-3,4$ & 3,2 & 2,6 & 72 & 6,8 \\
\hline March & 24,8 & $-2,0$ & 1,0 & 1,9 & 75 & 6,7 \\
\hline Apryl & 29,5 & 0,0 & 2,2 & 2,2 & 66 & 6,1 \\
\hline May & 29,2 & 4,7 & 1,8 & 1,6 & 71 & 6,2 \\
\hline June & 36 & 8,9 & 2,3 & 1,8 & 71 & 5,5 \\
\hline July & 37,2 & 11.9 & 2,3 & 2,1 & 64 & 3,9 \\
\hline August & 33,2 & 8,7 & 1,8 & 1,8 & 72 & 4,7 \\
\hline September & 31,1 & 4,5 & 2,0 & 1,3 & 73 & 4,7 \\
\hline October & 26,1 & $-0,5$ & 3,0 & 1,8 & 81 & 7,6 \\
\hline November & 21,7 & $-3,7$ & 2,2 & 1,9 & 76 & 6,0 \\
\hline December & 12,6 & $-9,5$ & 1,1 & 2,5 & 78 & 5,8 \\
\hline
\end{tabular}

Acetylene is stored in a cylinder where it is dissolved in acetone under 18 bar pressure so the damage on the cylinder causes a great deal of this gas to be released in the atmosphere in the aerosol form. Since acetylene is a highly flammable and explosive gas, there are various accident scenarios. Toxic effects of hazards were not considered since fire and explosion present by far the greatest danger of acetylene release. The model of spreading of vapor clouds formed by gas release, the model of jet fires formed by ignition in the cylinder, and the model of liquid expanding vapor explosions were all examined. Our main objective was to estimate endangerment of people and objects in the plant and its vicinity. 
As can be seen in Figure 3, the simulation in all these cases showed that acetylen was released from the cylinder in the form of aerosol at the speed of $1.57 \mathrm{~kg} / \mathrm{s}$. The total time of acetylene release was 60 seconds.

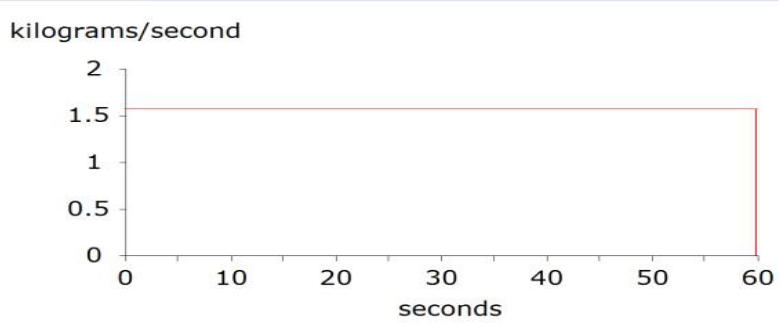

Figure 3. Chart of acetylene cylinder release speed.

The first scenario, given in Table 4, includes the release of non-burning acetylene forming a vapor cloud.

Table 4. Scenario 1 .

\begin{tabular}{|l|l|c|c|}
\hline \multicolumn{1}{c|}{$\begin{array}{c}\text { Threatening } \\
\text { danger }\end{array}$} & \multicolumn{2}{c|}{ Weather } & $\begin{array}{c}\text { Releasing } \\
\text { substance }\end{array}$ \\
\hline \multirow{4}{*}{$\begin{array}{l}\text { Acetylene release } \\
\text { without ignition } \\
\text { with formation of } \\
\text { flammable cloud }\end{array}$} & Temperature & $37,2^{0} \mathrm{C}$ & \\
\cline { 2 - 3 } & Wind (E) & $1,5 \mathrm{~m} / \mathrm{s}$ & \multirow{2}{*}{$\begin{array}{c}\text { Dilluted } \\
\text { acetylene }\end{array}$} \\
\cline { 2 - 3 } & Cloud cover & $4 / 10$ & \\
\cline { 2 - 3 } & Humidity & $64 \%$ & \\
\cline { 2 - 3 } & Stability Class & $\mathrm{F}$ & \\
\hline
\end{tabular}

In this case the areas with gas vapor air concentration within the limits of flammability, which can easily result in fire, were defined.

The results of this simulation, shown in Figure 4, show that at $53 \mathrm{~m}$ distance from the hazard location spot in the wind direction, the gas concentration in the atmosphere is higher than 15000 ppm being $60 \%$ of lower flammability limit and can therefore cause forming pockets of fire and generating fire (red zone). In this zone workers caught at their workplaces and the part of the factory in the vicinity are most threatened.

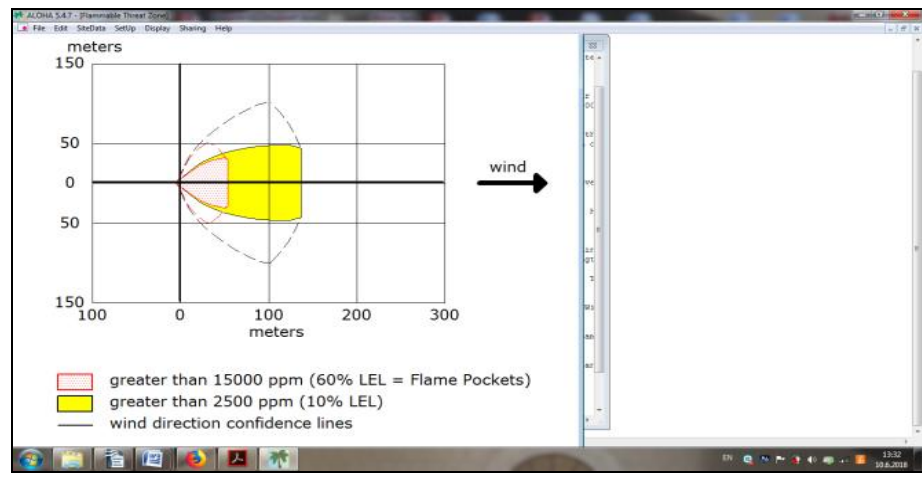

Figure 4. Characteristics of threat zones in Scenario 1.
The yellow zone occupies the area at $53 \mathrm{~m}$ to $138 \mathrm{~m}$ distance from the hazard source in the wind direction and it has a gas concentration of $2500 \mathrm{ppm}$ being $10 \%$ of lower flammability limit. As can be seen in Figure 5 in this zone about 15 residential buildings and a part of local road leading through the urban area would be directly endangered.

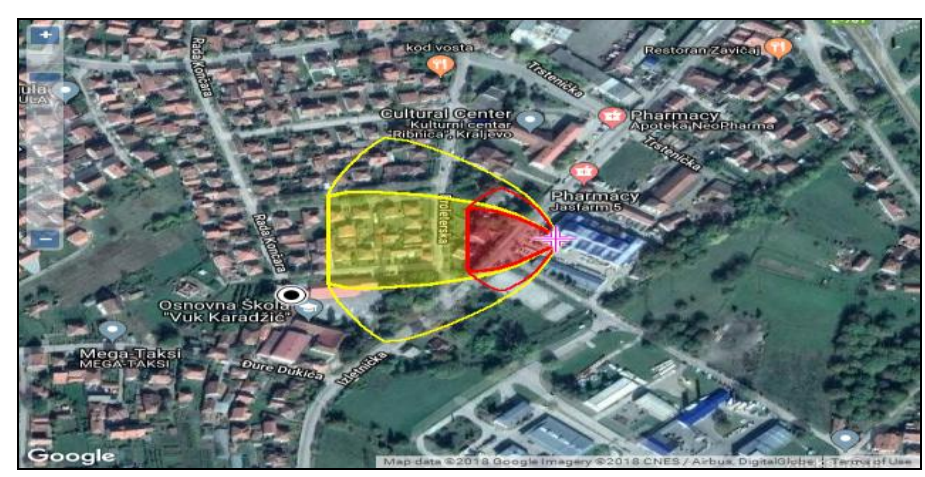

Figure 5. Zones of flammable acetylene cloud spreading in real space.

Although the second scenario, shown in Table 5, refers to the simulation of the accident under the same conditions, this simulation estimates the probability of forming an explosive zone caused by overpressure i.e. it defines the areas on which explosion of the formed acetylene cloud releasing into the atmosphere can occur.

Table 5. Scenario 2

\begin{tabular}{|l|l|c|c|}
\hline \multirow{2}{*}{$\begin{array}{c}\text { Threatening } \\
\text { danger }\end{array}$} & \multicolumn{2}{c|}{ Weather } & $\begin{array}{c}\text { Releasing } \\
\text { substance }\end{array}$ \\
\hline \multirow{4}{*}{$\begin{array}{l}\text { Acetylene release } \\
\text { without ignition } \\
\text { with formation of } \\
\text { explosive cloud }\end{array}$} & Temperature & $37,2^{0} \mathrm{C}$ & \\
\cline { 2 - 3 } & Wind (E) & $1,5 \mathrm{~m} / \mathrm{s}$ & \multirow{2}{*}{$\begin{array}{c}\text { Dilluted } \\
\text { acetylene }\end{array}$} \\
\cline { 2 - 3 } & Hloud cover & $4 / 10$ & \\
\cline { 2 - 3 } & Stability Class & $\mathrm{F}$ & \\
\cline { 2 - 3 } & & & \\
\hline
\end{tabular}

The simulation was performed for the detonation ignition occurred in the time period of 60 seconds after the gas release.

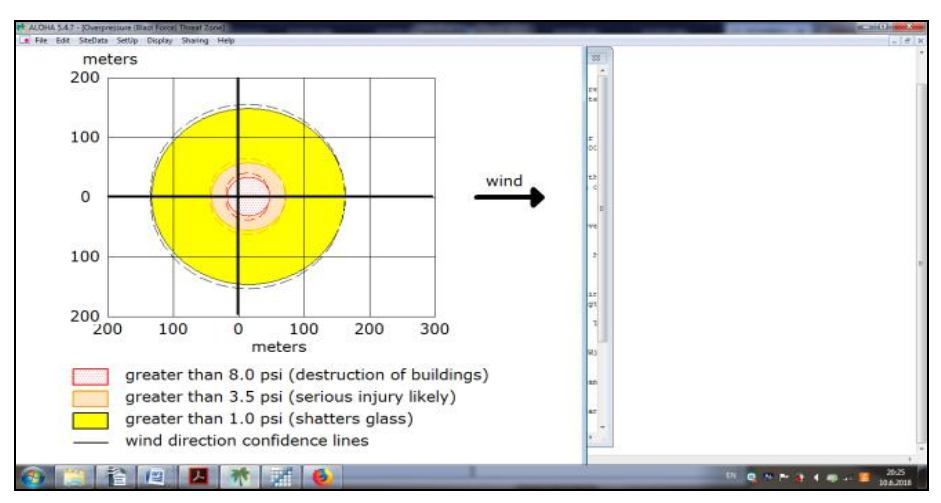

Figure 6. Characteristics of threat zones in Scenario 2. 
As can be seen from Figure 6, in this case, the most endangered zone encloses the diameter of $48 \mathrm{~m}$ (red zone) whose center is slightly shifted in the wind direction. In this zone under the pressure higher than $55.16 \mathrm{kPa}$ which has a destructive power, concrete buildings can be destroyed and human fatalities can be recorded. This scenario would include the warehouse of the plant and a part of the local road leading through the urban area. In the subsequent band placed at 48 to $72 \mathrm{~m}$ distance from the hazard source (orange zone), the pressure higher than 24.13 $\mathrm{kPa}$ can cause grave injuries and the destruction of light construction buildings. In the real space, shown in Figure 7, the orange zone includes a part of the plant, a part of the traffic road, sports facilities and a small number of residential buildings. The zone located at perimeter distance from 72 to $163 \mathrm{~m}$ (yellow zone) is the area under the pressure of $6.89 \mathrm{kPa}$. Minor injuries of people and slight building damages such as window cracking can be recorded in this zone. The yellow zone of this scenario would cover the Local Community Health Center, the Cultural Center, the primary school and about 20 residential buildings.

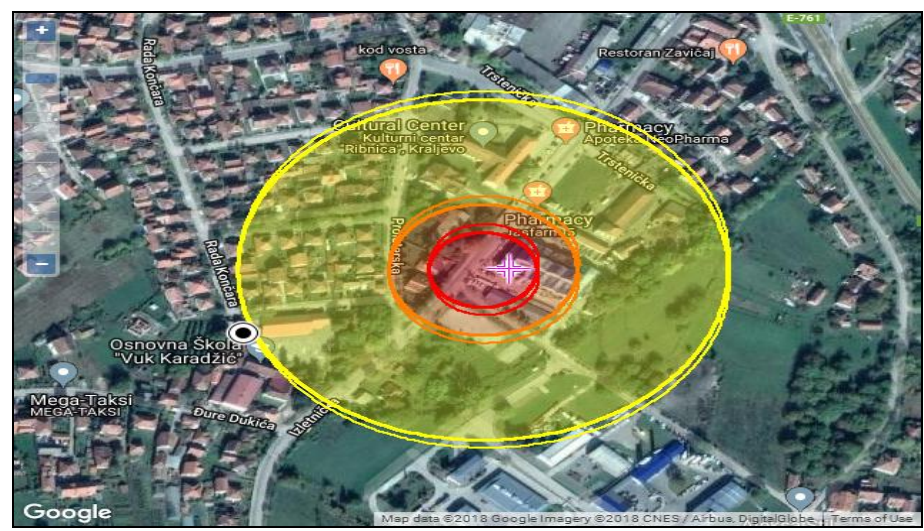

Figure 7. Zones of explosive acetylene cloud spreading in Scenario 2 in real space.

In the third scenario, given in Table 6, the release of dilluted acetylene in flame was predicted (fire in a tank, jet fire).

Table 6. Scenario 3 .

\begin{tabular}{|l|c|c|c|}
\hline \multirow{1}{*}{$\begin{array}{c}\text { Thretening } \\
\text { danger }\end{array}$} & \multicolumn{2}{|c|}{ Weather } & $\begin{array}{l}\text { Releasing } \\
\text { substance }\end{array}$ \\
\hline \multirow{3}{*}{$\begin{array}{l}\text { Release of } \\
\text { burning } \\
\text { acetylene jet } \\
\text { fire }\end{array}$} & Temperature & $37,2^{0} \mathrm{C}$ & \\
\cline { 2 - 3 } & Wind (E) & $1,5 \mathrm{~m} / \mathrm{s}$ & \\
\cline { 2 - 3 } & Cloud cover & $4 / 10$ & \multirow{2}{*}{$\begin{array}{c}\text { Dilluted } \\
\text { acetylene }\end{array}$} \\
\cline { 2 - 3 } & Humidity & $64 \%$ & \\
\cline { 2 - 3 } & Stability Class & $\mathrm{F}$ & \\
\hline
\end{tabular}

Thermal radiation is the threatening danger signalled by the software. As can be seen in Figure 8, three dangerous zones are also defined in this scenario.

The software predicted a $32 \mathrm{~m}$ long jet flame lasting for 20 seconds. In the $10 \mathrm{~m}$ radius red zone, thermal radiation with energy over $10 \mathrm{~kW} / \mathrm{m}^{2}$ is expected. This zone is potentially deadly and can cause severe burnings in only 60 seconds. The orange zone occupes the area at 10 to $23 \mathrm{~m}$ distance from the hazard source and is slightly shifted to the wind direction. Radiation energy in this zone reaches over $5 \mathrm{~kW} / \mathrm{m}^{2}$ causing second-degree burnings in only $60 \mathrm{~s}$. The third band of danger lies at 23 to $45 \mathrm{~m}$ distance from the accident spot. Thermal radiation of $2 \mathrm{~kW} / \mathrm{m}^{2}$ in this zone can cause mild burnings in 60 s. Figure 9 shows the thermal radiation zones of acetylene in scenario 3 in the real space. This scenario would assume that the part of the plant in the vicinity of the hazard source belongs to the red zone. Beside the part of the plant, the orange zone would include a segment of local traffic road, whereas the majority of storage facilities of the plant, a part of the traffic road and one residential building would belong to the yellow zone.

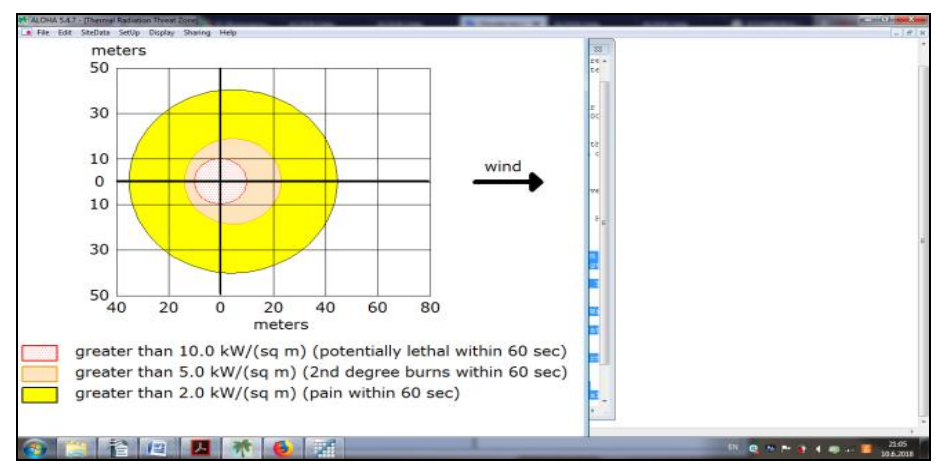

Figure 8. Characteristics of threat zones in Scenario 3.

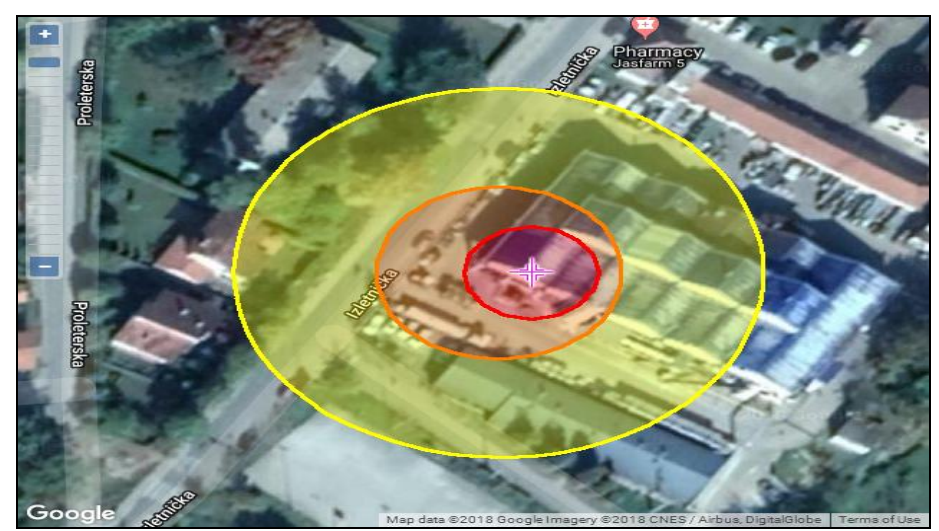

Figure 9. Zones of thermal radiation of acetylene in Scenario 3 in real space.

The fourth scenario, shown in Table 7, was modelled for the Boiling Expanding Vapour Explosion (BLEVE). Thermal radiation (surface heat flux of flame) of the burning tank is the danger predicted by the software.

Characteristics of threat zones in Scenario 4are given in Figure 10. In the fourth scenario, the software predicted the fire diameter of $31 \mathrm{~m}$ in only $3 \mathrm{~s}$. The red zone is the zone where the fire ball originates with energy flux higher than $10 \mathrm{~kW} / \mathrm{m}^{2}$ being potentially fatal to humans. The diameter of this zone reaches 74 $\mathrm{m}$. The next zone is the orange one occupying the band from 74 to $104 \mathrm{~m}$. This zone is characterized by thermal energy of 5 
$\mathrm{kW} / \mathrm{m}^{2}$ which can cause fires in buildings and serios burnings with people. The yellow zone is situated in the subsequent band which lies at 104 to $163 \mathrm{~m}$ distance from the accident. Energy of thermal flux in this band reaches $2 \mathrm{~kW} / \mathrm{m}^{2}$ and can result in minor burnings.

Table 7. Scenario 4.

\begin{tabular}{|l|c|c|c|}
\hline \multicolumn{1}{|c|}{$\begin{array}{c}\text { Threatening } \\
\text { danger }\end{array}$} & \multicolumn{2}{|c|}{ Weather } & $\begin{array}{c}\text { Releasing } \\
\text { substance }\end{array}$ \\
\hline \multirow{4}{*}{$\begin{array}{l}\text { Boiling } \\
\text { Expanding } \\
\text { Vapour } \\
\text { Explosion }\end{array}$} & Temperature & $37,2^{0} \mathrm{C}$ & \\
\cline { 2 - 3 } & Wind (E) & $1,5 \mathrm{~m} / \mathrm{s}$ & \multirow{2}{*}{$\begin{array}{c}\text { Dilluted } \\
\text { acetylene }\end{array}$} \\
\cline { 2 - 3 } & Cloud cover & $4 / 10$ & \\
\cline { 2 - 3 } & Humidity & $64 \%$ & \\
\cline { 2 - 3 } & Stability Class & $\mathrm{F}$ & \\
\hline
\end{tabular}



Figure 10. Characteristics of threat zones in Scenario 4.

Zones of thermal radiation of acetylene in Scenario 4 in real space are given in Figure 11. This scenario implies that the red zone would inlcude broader part of the plant complex area, a segment of the traffic road, playground, Health Center and 5-6 residential buildings. The orange zone would include a segment of the traffic road and 5 residential buildings. Cultural center, around 20 residential buildings and the acetylene production plant segment would belong to the yellow zone.

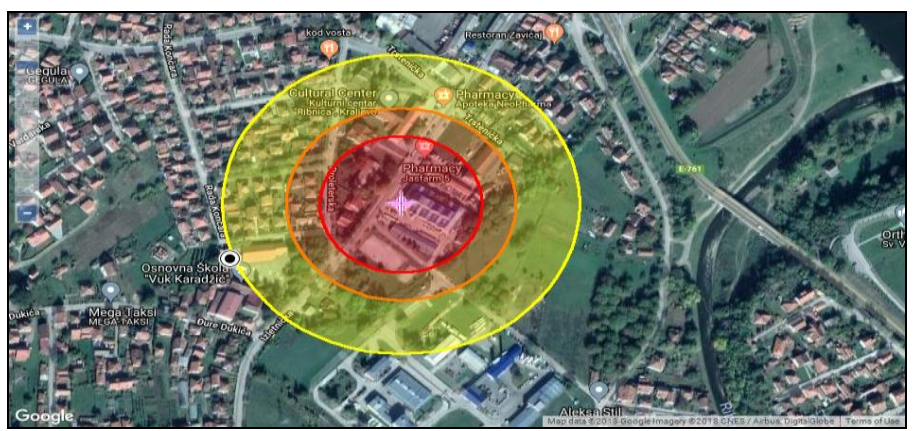

Figure 11. Zones of thermal radiation of acetylene in Scenario 4 in real space

\section{CONCLUSION}

The simulations of various acetylene cylinder release scenarios indicate the high risk of fire in explosion and significant endangerment of working and natural environment in Messer Tehnogas Kraljevo plant. The most endangered zone is the warehouse with different gases. Bearing in mind that acetylene is storaged in this zone, it can be logically deduced that fire or explosion of only one acetylene cylinder can trigger the avalanche of uncontrolled explosions and fires. This generates the so called "domino effect" whose consequences are far more serious than the described ones.

Together with assessment of safety and threat zones, ALOHA sotware program provides proper risk managament planning and improvement of people and object safety in the surroundings. According to damage risk estimates, this program contributes to taking adequate measures in order to prevent potential accidents in chemical plants. The simulation is substantially cheaper solution compared to in vivo experiments since it saves material, financial, and temporal resources.

\section{REFERENCES}

Abbasi, T., Ramasamy, E.V., Khan, F.I., \& Abbasi, S.A. 2013. Regional EIA and Risk Assessment in a Fast Developing Country. New York: Nova Science. pp. $x+433$.

Bogdanović, M. 2008. Faze nastajanja akcidenata i mere zaštite od posledica hemijskih akcidenata. Facta universitatis series: Working and Living Enviromental Protection; Niš, Vol. 5, No 1, pp. 89-95.

Bogdanović, M. 2009. Widely known chemical accidents. Facta universitatis -series: Working and Living Environmental Protection; Niš, Vol. 6, No 1, pp. 65-71.

Carver, F.W.S., Smith, C.M., \& Webster, G.A. 1972. The explosive decomposition of acetylene in pipelines. In I.Chem.E. Symposium Instn chem. Engrs, London. Series No. 33.

Crowl, D.A., \& Louvar, J.F. 2011. Chemical Process Safety: Fundamentals with Applications. Boston: Pearson Education.

Cvetanović, S. 2015. Integral model of systemic approach to risk management of chemical accidents at the local level. Niš: Faculty of Occupational Safety. Doctoral dissertation.

El, H.M., Mustapha, S., Choong, T.S.Y., Abdul, R.S., Kadir, S.A.S.A., \& Abdul, R.Z. 2008. Rapid analysis of risk assessment using developed simulation of chemical industrial accidents software package. International Journal of Environmental Science \& Technology, 5(1), pp. 53-64. doi: $10.1007 / \mathrm{bf} 03325997$

Huang, D., Zhang, Q., Li, M., \& Liu, M. 2015. Example application of risk assessment technology based on acute poisoning accident dispersion simulation. In 5th International Conference on Risk Analysis and Crisis Response, RACR; Tangier; Morocco. Pages 349-357.

Jovanović, T. 2013. The analysis and the simulation of fire risk in the facility for fruit treatment "Pobeda" in Prokuplje. Safety Engineering, pp. 183-187.

Khan, F.I., \& Abbasi, S. 1998. Techniques and methodologies for risk analysis in chemical process industries. Journal of Loss Prevention in the Process Industries, 11(4), pp. 261-277. Discovery Publishing House, New Delhi. doi:10.1016/s09504230(97)00051-x 
Khan F.I., \& Abbasi S.A. 1998. Domiefect: (domino effect) a user-friendly software for domino effectanalysis. Environmental Modelling and Software, 13(2), pp. 163-177. doi:10.1016/s1364-8152(98)00018-8

Khan, F.I., \& Abbasi, S. 2001. An assessment of the likelihood of occurrence, and the damage potential of domino effect (chain of accidents) in a typical cluster of industries. Journal of Loss Prevention in the Process Industries, 14(4), pp. 283306. doi:10.1016/s0950-4230(00)00048-6

Lakshmanan, T., \& Nagarajan, G. 2010. Experimental investigation of timed manifold injection of acetylene in direct injection diesel engine in dual fuel mode. Energy, 35(8), pp. 3172-3178. doi:10.1016/j.energy.2010.03.055

Lakshmanan, T., \& Nagarajan, G. 2011. Study on using acetylene in dual fuel mode with exhaust gas recirculation. Energy, 36(5), pp. 3547-3553. doi:10.1016/j.energy.2011.03.061

Mannan, S. 2013. Lees' Process Safety Essentials: Hazard Identification, Assessment and Control. ButterworthHeinemann. book.
Sanchez, E.Y., Represa, S., Mellado, D., Balbi, K.B., Acquesta, A.D., Colman, L.J.E., \& Porta, A.A. 2018. Risk analysis of technological hazards: Simulation of scenarios and application of a local vulnerability index. Journal of Hazardous Materials, 352, pp. 101-110. doi:10.1016/j.jhazmat.2018.03.034

Sanders, R.E. 2015. Chemical Process Safety: Learning from Case Histories.Butterworth-Heinemann, book.

Sarkar, S. 1990. Fuels and combustion.Mumbai, India: Orient Longman Limited.

Sengupta, A., Bandyopadhyay, D., van Westen, C.J., \& van der Veen, A. 2016. An evaluation of risk assessment framework for industrial accidents in India. Journal of Loss Prevention in the Process Industries, 41, pp. 295-302. doi:10.1016/j.jlp.2015.12.012

Shao, H., \& Duan, G. 2012. Risk Quantitative Calculation and ALOHA Simulation on the Leakage Accident of Natural Gas Power Plant. Procedia Engineering, 45, pp. 352-359. doi:10.1016/j.proeng.2012.08.170

Varma, R., \& Varma, D.R. 2005. The Bhopal Disaster of 1984. Bulletin of Science, Technology \& Society, 25(1), pp. 37-45. doi:10.1177/0270467604273822 